UDC 553. 98(479.24): 550.8.072

\title{
О ТИПАХ ЛОВУШЕК, СФОРМИРОВАВШИХСЯ В КУРИНСКОЙ И ЮЖНО-КАСПИЙСКОЙ ВПАДИНАХ И РОЛИ ТЕКТОНИЧЕСКИХ НАРУШЕНИЙ В НИХ
}

\author{
Мухтарова Хураман Зиядхан гызы, \\ mukhtarova.khuraman@mail.ru \\ Азербайджанский Государственный Университет Нефти и Промышленности, \\ Азербайджан, AZE1010, г. Баку, пр. Азадлыг, 34.
}

\begin{abstract}
Актуальность исследования обусловлена тем, что в Азербайджане, как и во всем мире, месторождения нефти и газа, связанные с антиклинальными типами ловушек, стремительно исчерпываются. Именно эта ситуация оставляет за собой актуальность и требует изучения разнотипных, в основном неантиклинальных и комбинированных, ловушек и их перспективность (где немалое значение имеют тектонические нарушения). Проведенные нами исследования могут предоставить достоверную информацию по изучению ловушек и в Куринской, и в Южно-Каспийской впадинах, которые развивались абсолютно в разных геолого-тектонических условиях.

Цель: определение характера тектонического развития структур Куринской и Южно-Каспийской впадин и анализ строения сформировавшихся в них разнотипных ловушек.

Методы. С помощью компьютерной программы (ArcGis - Architecture Geograophical Information Sistem) построена модель территории и реконструированы палеотектонические условия, наглядно иллюстрирующие развитие и положение исследуемых впадин. В результате моделирования и исследования палеотектонического развития региона было выявлено, что если в песчаных горизонтах продуктивной толщи Южно-Каспийской впадины ловушки характеризуются антиклинальным типом, то в Куринской впадине они связаны в основном с породами возрастов палеоген-миоцена, эоцена и верхнего мела и приурочены к неантиклинальным типам ловушек.

Результаты. Ловушки антиклинального типа формируются в основном в результате горизонтальных тектонических напряжений, а неантиклинальные ловушки полностью формируются, отражая различные стадии эволюции земной коры. Именно тектонические движения имеют немалую роль в определении различных фоорм геологических тел и геометрических единии, в которых образуются разнотипные ловушки, которые морфологически отличаются друг от друга, в зависимости от воздействия главного фрактора и условий формирования. Нашими исследованиями было выявлено, что в Южно-Каспийской впадине в основном развиты тектонически экранированные залежи, тогда как Куринская впадина является территорией формирования преимущественно залежей массивного типа, связанных с эрозионными выступами фундамента и эфффузивными «ядрами». Изучение этих вопросов позволяет прогнозировать перспективность поиска сложных по геометрическим данным и форме ловушек. Наряду с этим изучение условий формирования разнотипных ловушек дает возможность определить как их литологический состав, так и ареалы их распространения. Было определено, что пространственное положение структур Куринской впадины в определенной степени отличается от структур Южно-Каспийской впадины с точки зрения закономерностей пространственной ориентации. Другими словами, в Куринской впадине не особо удается обнаружить определенную организацию в расположении структур, тогда как складки Южно-Каспийской впадины явно наводят на мысль о воздействии сжимающих напряжений и их преобладающей роли в ориентации поднятий. На рассматриваемой территории ловушки антиклинального, неантиклинального и комбинированного типов наблюдаются в основном в глубокопогруженных отложениях и представляют немалый интерес с точки зрения поисков нефтегазовых месторождений. Нельзя не учитывать, что в результате тектонических и других воздействий, которые неоднократно повторялись, сфрормированные ловушки имеют более сложную форму.
\end{abstract}

\section{Ключевые слова:}

Антиклиналь, неантиклиналь, резервуар, уелеводороды, движения, экран, процесс, выклинивание, ловушка, нефрть, газ, залежь.

\section{Введение}

Изучение условий формирования и размещения антиклинальных (АЛ), неантиклинальных (НАЛ) и комбинированных ловушек (КЛ) нефти и газа даёт возможность определить основные места их образования. Анализ условия формирования ловушек показывает, что НАЛ в основном наблюдаются в бортовых частях палеобассейнов, впадин и прогибов, которые сильно осложнены разрывными нарушениями. В палеодельтах и палеоруслах рек формируются НАЛ рукавобразного, гнездообразного и линзавидного типа. НАЛ, осложненные грязевым или палеовулканизмом, представляют немалый интерес, т. к. были обнаружены месторождения, связанные с этими ловушками, которые имели большие запасы нефти и газа [1-8].
При выделении НАЛ надо учитывать генетический тип осадочного бассейна, т. к. именно этот фактор предопределяет формирование определенных типов НАЛ. Выявление и построении структурных карт по кровле или подошве ловушки основываются на обнаружении ее образа в сейсмическом разрезе. При этом необходимо установить наличие пластовколлекторов, которые распознаются по рисунку сейсмической записи с высоким разрешением [9-16]. По генезису и структуре среди ловушек неантиклинального типа, выявленных в Южно-Каспийской мегавпадине (ЮКМВ), можно выделить ловушки: литологические, стратиграфические, литостратиграфические экраны, массивные, аккумулятивные, эрозионные тела и др. Они образовались в толщах, сформированных на различных этапах эволюции ЮКМВ. В зависимости от характера тектонических процессов в па- 
леобассейнах условия осадконакопления и другие процессы определяли литологический состав пород, тип и особенности распределения коллекторов и ловушек на изучаемой территории, т. е. наблюдаемая на сейсморазрезах картина является результатом исторического развития региона. Поэтому прогноз литофаций, материнских пород и коллекторов, на участках распространения которых отсутствуют данные бурения, должен выполняться на основе модели исторического развития региона (рис. 1).

\section{Методы}

Относительно перспективы нефтегазоносности, которая зависит от формы и типа ловушек в ЮКМВ, можно сказать, что моделирование структуры земных недр в пределах Южно-Каспийской [17] и Куринской впадин (рис. 1) позволяет обосновать формирование различных типов ловушек, в частности нестандартных.

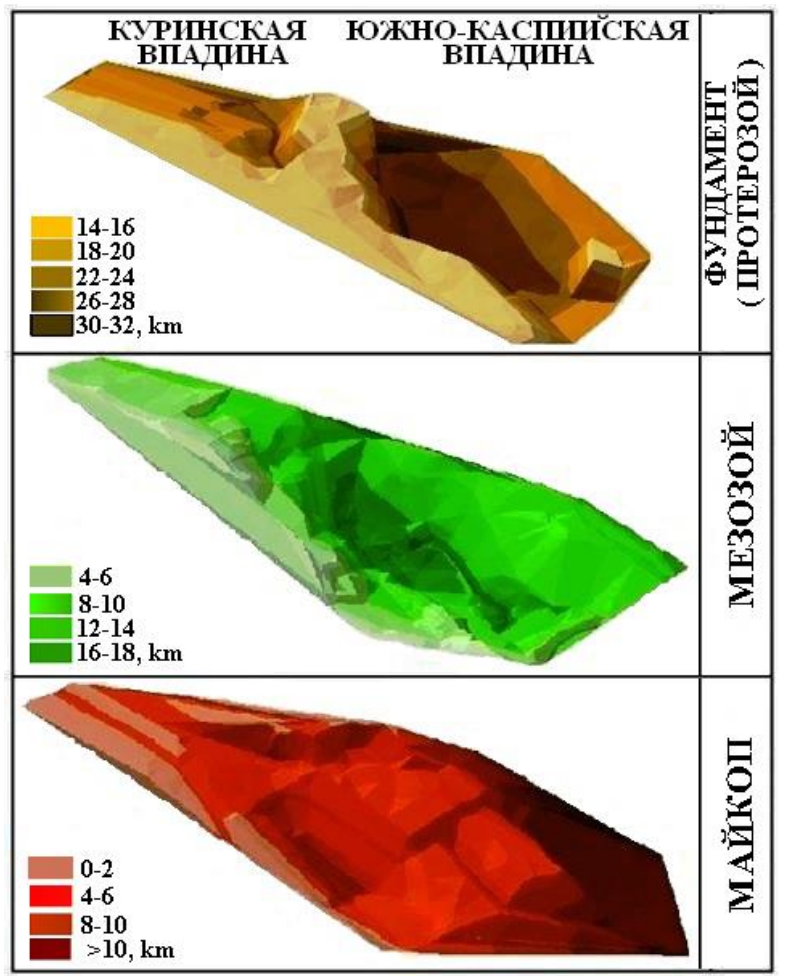

Рис. 1. Модели развития Куринской и ЮжноКаспийской впадин в различных временных интервалах (по Х.З. Мухтаровой). Разность глубин соответствуюших поверхностей обозначена оттенками цвветов

Fig. 1. Models of evolution of the Kur and South Caspian depressions at different time intervals (after Kh.Z. Mukhtarova). The difference in depth of the corresponding surfaces is indicated by shades of colors

Изучая тектонические особенности развития ЮКМВ и её структуры, можно прийти к выводу о том, что разрывные нарушения, осложняющие данные структуры, могут способствовать как разрушению, так и формированию месторождений. Этот факт относится к УВ залежам в продуктивной толще (ПТ) и подстилающих её отложениях. Одни и те же разрыв- ные нарушения могут быть в одной части структуры проводящими, а в другой - экранирующими.

Роль тектонических разрывов в формировании и разрушении залежей УВ нами рассмотрена в Куринской и Южно-Каспийской впадинах. Как видно из моделей, построенных для майкопа (олигоцен-нижнего миоцена), мезозоя (верхний мел) и фундамента протерозойского возраста, их тектоническое развитие и особенности проявляли себя в различных промежутках геологического времени не единообразно. Эти особенности дают возможность охарактеризовать формирование и размещение залежей нефти и газа на разных этапах развития исследуемой территории. Изучая эти особенности, приводим несколько примеров эволюции структур, которые развивались при различных условиях в пределах исследуемой территории.

Осадочные тела, облекающие либо порой заполняющие формы палеорельефа, образуют НАЛ в виде речных палеоврезов, прирусловых валов и борозд, сформированных речными потоками. Речные палеоврезы, очевидно, сложены обломочным (песчаным) материалом с высокой пористостью и хорошими коллекторскими свойствами.

В регионе карбонатные массивы, рифы (барьерные, краевые) и банки представляют собой зоны распространения ловушек нефти и газа. С этой точки зрения особенно отличается Кринская впадина, где ловушки этого типа (рис. 2, 3) выявлены в ряды больше, чем в ЮКВ.

Для диагностики рифов используется ряд критериев, таких как отсутствие отражений в сейсмических разрезах, высокая скорость распространения в них сейсмических волн, а также положение рифа относительно шельфа, присутствие субпараллельных отражений вне рифа. Над рифами часто наблюдается эффект уплотнения.

В окружении выше- и нижележащих отложений рифы являются резко контрастными объектами, как по литологическому составу, так и по морфологии, что обуславливает эффективность сейсмостратиграфического подхода при их поиске. Надо отметить, что барьерные рифы особенно рельефно выделяются на сейсморазрезах выпуклой формой кровли при плоской подошве, что было отмечено на юрско-меловой террасе Северо-Абшеронского мезозойского вала. Рифы отличаются аномальными скоростями распространения сейсмических волн по сравнению к сопряженным участкам бровки шельфа $[11,12]$.

Большая группа НАЛ образовалась в территориях конседиментационного налегания слоев в зонах прогибания и включения их в область седиментации. НАЛ конседиментационного налегания широко распространены в Нижнекуринской и центриклиналях ЮКВ. На месторождениях Мишовдаг, Гырлыг и Галмаз сформировались НАЛ, именно в связи с конседиментационным развитием структур, обусловленных дифференцированным прогибанием внутреннего шельфа и выклиниванием отложений на периферии мелководного плиоценового бассейна. Поступление терригенного материала из источника сноса, наложенное на тектоническое прогибание, способствовало 
фациальному замещению и перекрытию коллекторов непроницаемыми породами. Поднятие вышеуказанных структур в процессе их формирования под воздействием сжимающих напряжений и положительных тектонических движений способствовало образо- ванию тектонических нарушений, в результате чего, ввиду конседиментационной природы процесса, образовались как тектонически экранированные ловушки, так и ловушки, связанные с выклиниванием пластов (рис. 4) [18-20].

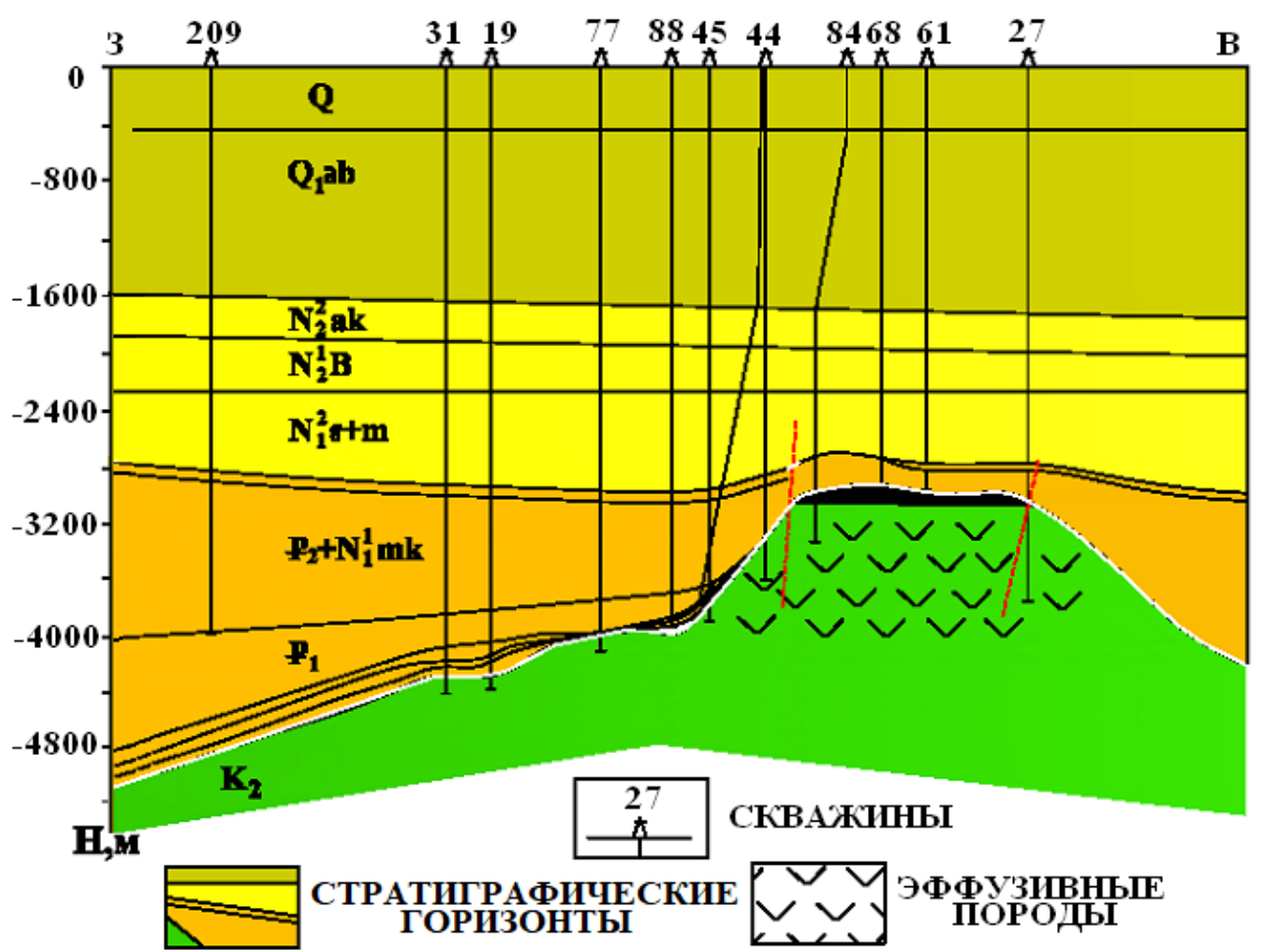

Pис. 2. Площадь Мурадханльь. НАЛ, связанные с выступом эффузивных пород [18]

Fig. 2. Muradkhanli field. NAT (non-anticline traps) associated with a projection of effusive rocks [18]

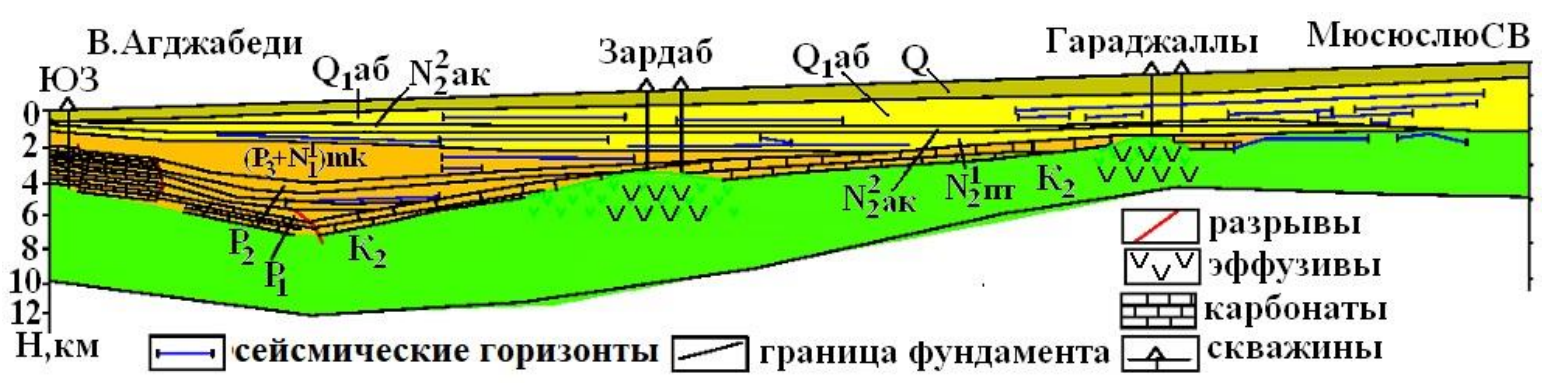

Pис. 3. Региональный профиль, проходящий через Среднекуринскую впадину по линии Восточный АгджсабедиМюсюслю. НАЛ, связанные с выступами эффузивных пород [18]

Fig. 3. Regional profile crossing the Middle Kur depression along the Eastern Agjabedi-Mususlu line. NAT associated with projections of effusive rocks [18]
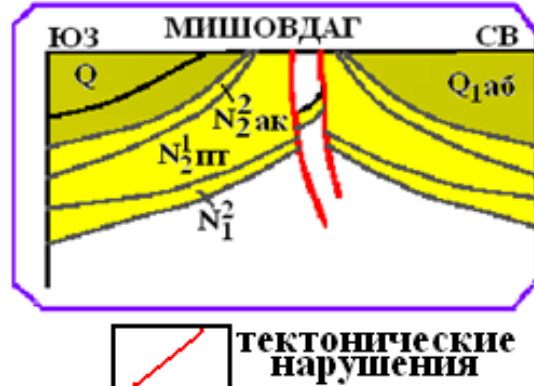

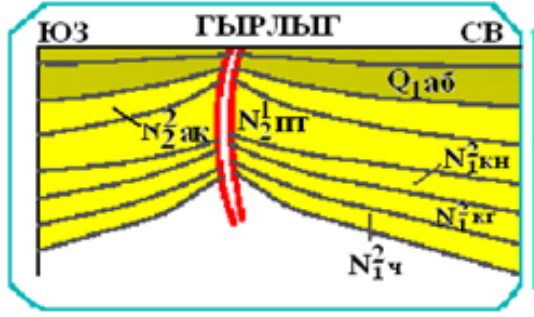

стратитрафические

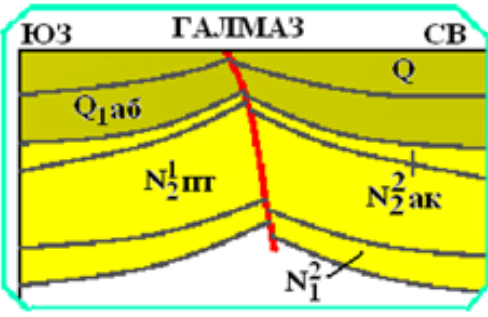

N TIт горизонты,

Pис. 4. Структуры, относящиеся к Нижнекуринской впадине. НАЛ конседиментационного характера [21]

Fig. 4. Structures associated with the Lower Kur depression. NAT of konsedimentatsionny nature [21] 
Для правильной оценки перспектив нефтегазоносности осадочного чехла в пределах исследуемой территории необходимо изучение глубинного строения вместе с детальным анализом истории геологического развития ЮКМВ.

Исследование современной структуры ЮКМВ совместно с изучением подстилающих пластов способствует выявлению зон, благоприятных для формирования ловушек как антиклинального, так и неантиклинального типов.

Влияние некоторых тектонических факторов в западном шельфе ЮКБ способствовало созданию благоприятных условий для формирования НАЛ.

Отличительной и одновременно уникальной чертой этих условий является регулярная лавинная седиментация, как, например, в случае с продуктивной толщей нижнего плиоцена. Чередование глин и песчаников явилось причиной формирования разномасштабного и вместе с тем ритмичного разреза. При частых переменах состава литофаций в осадочном разрезе изучаемой территории, в направлениях восстания и погружения общей складчатости, наблюдается усложнение стратиграфических единиц разреза ПТ, сопровождаемое выклиниванием и разномасштабными разрывами в осадочной толще.

Недостаточная изученность осадконакопления с тектонической и литолого-стратиграфической точек зрения не дают возможность детально охарактеризовать УВ системы Каспийского шельфа, что требует проведения комплексных исследований.

В Южно-Каспийской впадине (ЮКВ) УВ залежи формировались в основном в песчаных горизонтах ПТ. Проведение вышеуказанных исследований также необходимо для более основательного изучения особенностей геологического строения ловушек, сформировавшихся в палеоген-миоценовых отложениях.

По генетическим и морфологическим особенностям ловушки в данных отложениях могут быть различными, но в общем их можно отнести к структурному, литологическому и комбинированному (структурностратиграфическому, структурно-литологическому) типам. В результате смятия пластов осадочного чехла в антиклинальные складки формируются структурные ловушки, благоприятные для скопления УВ. В процентном отношении объем такого вида складок больше объема литологических ловушек. Процесс формирования литологических ловушек протекает одновременно с процессом осадконакопления, например, при перекрытии глинами линзообразных, шнуркообразных, баровых песчаных тел.

Такие ловушки могут формироваться в результате замещения песчаных пород на глинистые, либо наоборот. Для некоторых участков присутствия отложений палео-Волги и палео-Куры (для абшеронского яруса и продуктивной толщи) отмечаются осадки дельтовых рукавов, дельтовых низменностей и русел некрупных рек.

Мало изученным примером комбинированных ловушек могут служить структурно-стратиграфические ловушки. В ЮКВ эти ловушки сформировались в размытых приподнятых частях антиклинальных и моноклинальных структур. В этих ловушках песчанистые горизонты палеоген-миоценовых отложений трансгрессивно перекрыты глинами понтского возраста или более древними ярусами миоцена.

Формирование структурно-стратиграфических ловушек отличается от формирования структурнолитологических. Последние формируются в результате фациального замещения, в основном - глинизации песчаных горизонтов палеоген-миоцена и ПТ, что часто наблюдается в крыльевых частях антиклинальных структур или же в приподнятых частях моноклиналей. Выявить эти ловушки методами сейсморазведки сложно. Тем не менее в пределах ЮКМВ в результате геофизических исследований в больших количествах были выявлены многообразные типы ловушек, в которых были обнаружены не один десяток миллионов тонн запасов УВ [22].

Поднятия Гум-дениз и Бахар (рис. 5, 6), как и большинство структур, расположенных в западном шельфе ЮКВ, подвергались многократному влиянию тектонических движений, в результате чего были сильно осложнены многочисленными поперечными и продольными нарушениями. Образовавшиеся здесь несколько тектонических блоков отличаются друг от друга перспективами нефтегазоносности [23].

Тектонические разрывы в разных отделах ПТ отличаются друг от друга по многим параметрам и играют различную роль в формировании залежей нефти и газа. Поперечный разрыв на площади Гум-дениз разделяет структуру на северную и южную части, и для залежей нижнего отдела ПТ он играет проводящую роль, тогда как залежи верхнего отдела экранируются этим же тектоническим нарушением $[1,3,23]$.

Полученные из эксплуатационных скв. № 49, 58, $63,66,531,626$ и др. данные по подкирмакинской (ПК) свите подтверждают проводящий характер этого разрывного нарушения. Сбросовый характер рассматриваемого «разрыва» в пределах северовосточного крыла складки играет проводящую для УВ роль в пределах ПК свиты, тогда как разномасштабное взбросовое разрывное нарушение в пределах юго-западного крыла для той же свиты является экраном и в формировании УВ залежей играет значительную роль. Продольные разрывы, осложняющие северную и южную части складки, являются экраном для залежей всей ПТ. Некоторые участки исследуемой территории вполне могут быть исключением именно для свиты ПК в плане проводимости либо экранирования. Вдоль северного продольного разрыва, на западном и восточном участках, были пробурены эксплуатационные скважины, информация по которым доказала данные утверждения. Например, получение из свиты ПК пластовой воды в скв. 48, 70, 71 и нефти и газа в скв. 4, 6, 66 и т. д. Литологическая неоднородность, прослеживаемая по всему разрезу, может служить рациональным объяснением этому. В противном случае должны были бы наблюдаться проявления нефти и газа при миграции УВ (как боковой, так и вертикальной) через продольный разрыв.

Распределение залежей УВ на месторождении Гум-дениз, а также изменение нефтенасыщенности 
ловушек в сторону уменьшения с глубиной происходили благодаря горизонтальной и вертикальной миграции. Продольные и поперечные разрывы, осложняющие условия формирования залежей антиклинального типа, имеют постседиментационный характер и не всегда создают благоприятные условия для формирования залежей. Так, вертикальная миграция флюидов, происходящая по этим нарушениям вверх по разрезу, может иметь как благоприятный, так и отрицательный итог при формировании залежей. В первом случае в результате миграции может формироваться залежь, а во втором - уже сформировавшаяся залежь будет подвергнута разрушению (рис. 5) $[1,6]$.

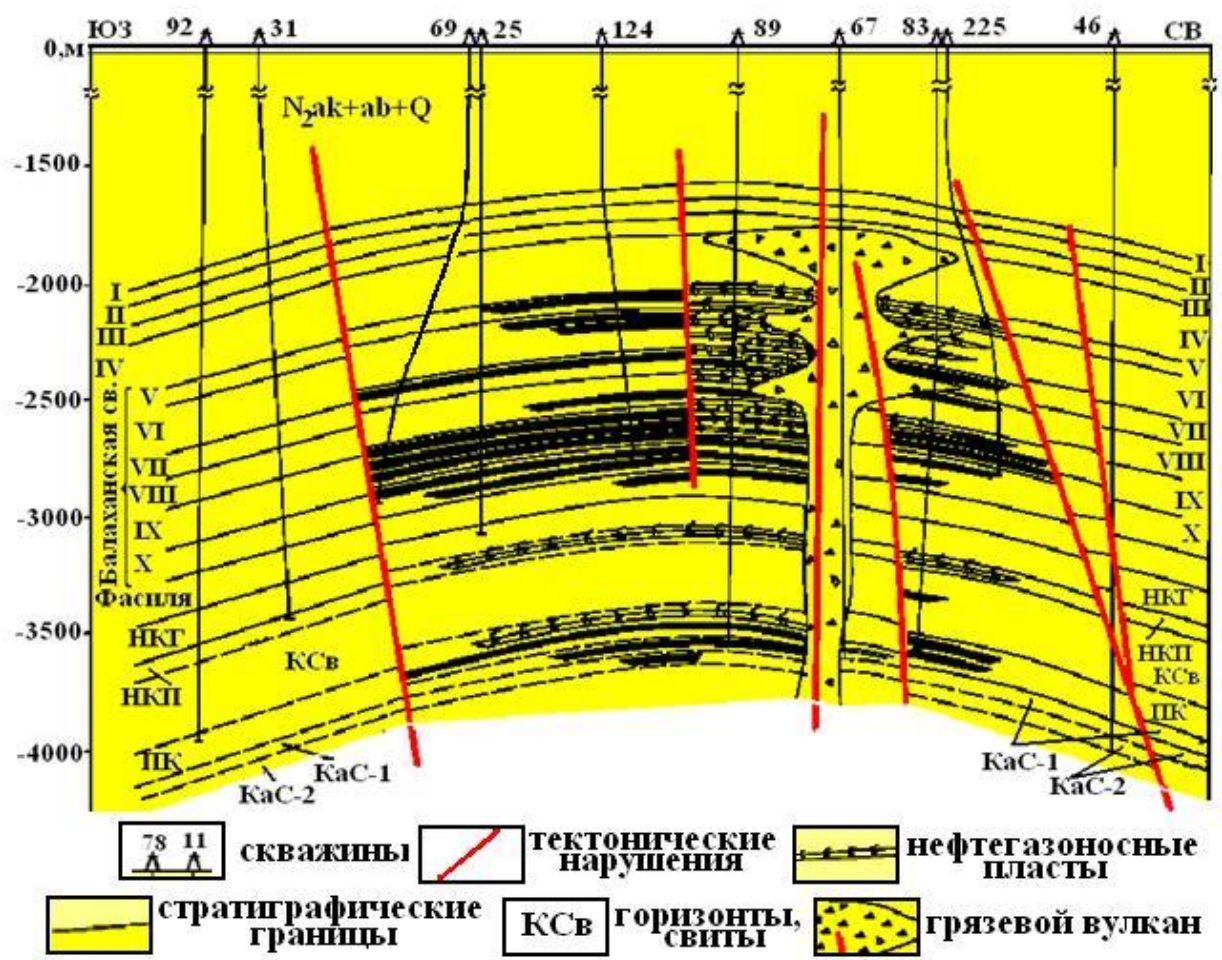

Pис. 5. Геологический профиль площзади Гум-дениз [23]

Fig. 5. Geological profile of the Gum-deniz field [23]

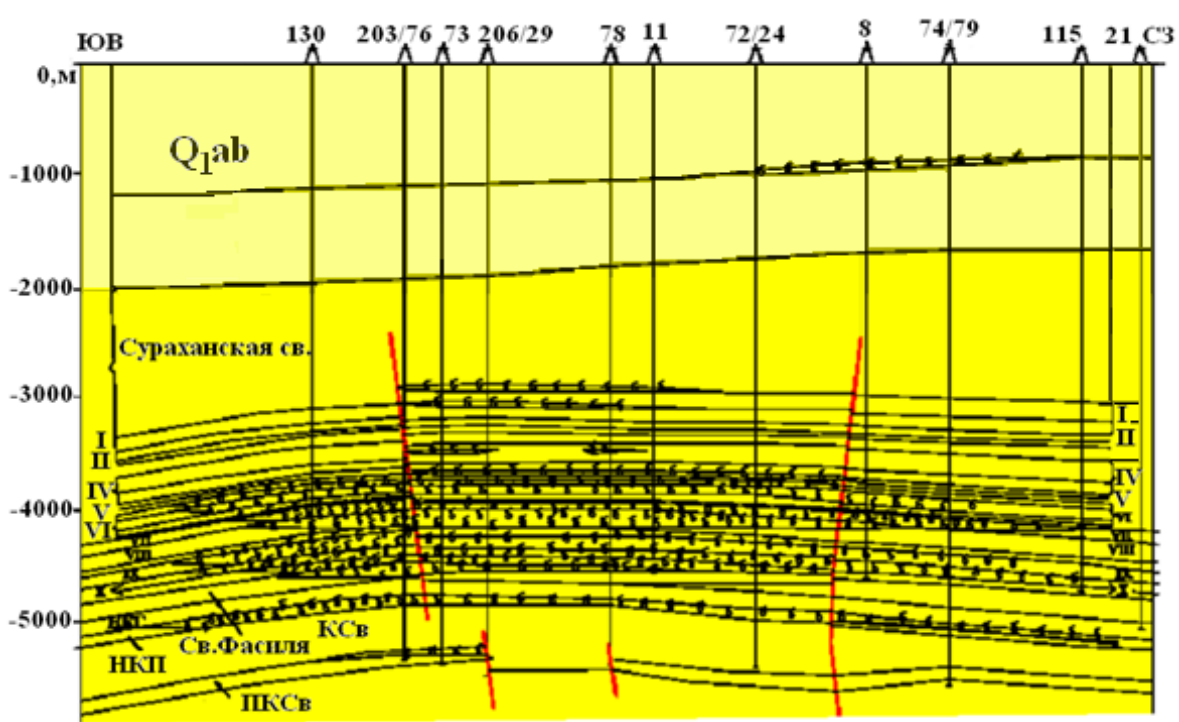

\section{$\stackrel{78}{11}$ скважины $>$ тектоншческие

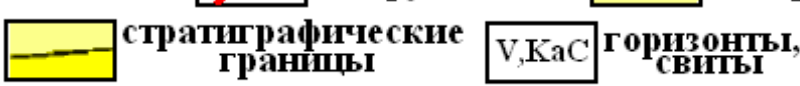

Pис. 6. Сейсмогеологический профиль площади Бахар [23]

Fig. 6. Seismogeological profile of the Bahar field [23] 
Структура Бахар также осложнена серией поперечных и продольных разрывных нарушений. В результате этих нарушений осложнены юго-западное и северо-восточное крылья структуры.

Продольные разрывы осложняют северовосточное крыло структуры и являются проводящим для балаханской свиты. Скважины 12, 46, 77 и др., расположенные вдоль всей протяженности этого разрыва, подтвердили проводимость нарушений по результатам опробования. Имеющий экранирующий характер для залежей свит НКП и ПК в частности и для нижнего отдела ПТ в целом продольный разрыв нарушает свод складки, отделяя его юго-западное крыло. При детальном изучении природы разрывов, которые осложняют структуру, было выявлено, что приподнятая центральная (сводовая) часть складки имеет горстовый характер. При этом наблюдается «ступенчатый» подъем разрывных нарушений в восточном направлении.

С увеличением глубины бассейна «ступенчатость» становится более выраженной. Наблюдая эти изменения, можно прийти к выводу, что тектоническое погружение бассейна в нижнем плиоцене имело интенсивный характер (рис. 6).

На площади Бахар ПК свита вскрыта более чем десятью скважинами $(12,19,50,54,59,65,66,71,73$, 74,78 и др.), на северном крыле структуры и в сводовой (центральной) части. В опробованных скв. 71 и 74 отсутствовал приток, а в скв. 50 была получена пластовая вода. Из расположенных в сводовой части структуры скв. 56, 66 и 73 при опробовании различные интервалы дали промышленный приток газа и газконденсата. Незначительный приток нефти был получен из скв. 78. Кроме сводовой части, нефтегазоносной оказалось и северо-восточное крыло структу- ры. Исследования показали, что и на площади Бахар тектонические нарушения остаются главным фактором распределения УВ как по разрезу, так и по площади.

Рассматривая структуры, в которых сформировались УВ залежи (на западном борту ЮКВ), не сложно заметить, что, как и на месторождении Сангачалдениз-Дуванны-дениз-Хара-Зыря, все месторождения сильно осложнены разрывными нарушениями. До середины прошлого столетия было принято, что основное продольное нарушение, проходящее в районе скв. $28,30,39,82,90,549$ и 564, на этом месторождении являлось экранирующим. Полагалось, что именно миграция флюидов с северо-востока была основным фактором образования залежей нефти и газа на соответствующем крыле структуры Дуванны-дениз. Однако в результате более детальных поисковоразведочных работ было установлено, что промышленные скопления УВ в повышенных частях структуры отсутствуют $[1,3]$.

Поперечное нарушение северо-восток-юго-западного направления на месторождении Дуванны-дениз (рис. 7) является экраном для $\mathrm{VII}^{\mathrm{x}}$ горизонта, а также, вполне возможно, и для нижележащих нефтеносных горизонтов. На основе опробования скв. 19, 28, 29, 64 и 96, которые расположены на различных частях месторождения Сангачал-дениз-Дуванны-дениз-ХараЗыря, можно сделать выводы о том, что продольный разрыв стал главной причиной разрушения залежей, сформировавшихся в VIII горизонте в сводовой части структуры. Пластовая вода, полученная при опробовании VIII горизонта ПТ, приводит к мнению о том, что условия формирования залежей VII и VIII горизонтов являются различными, хотя их и ограничивают единые тектонические нарушения.

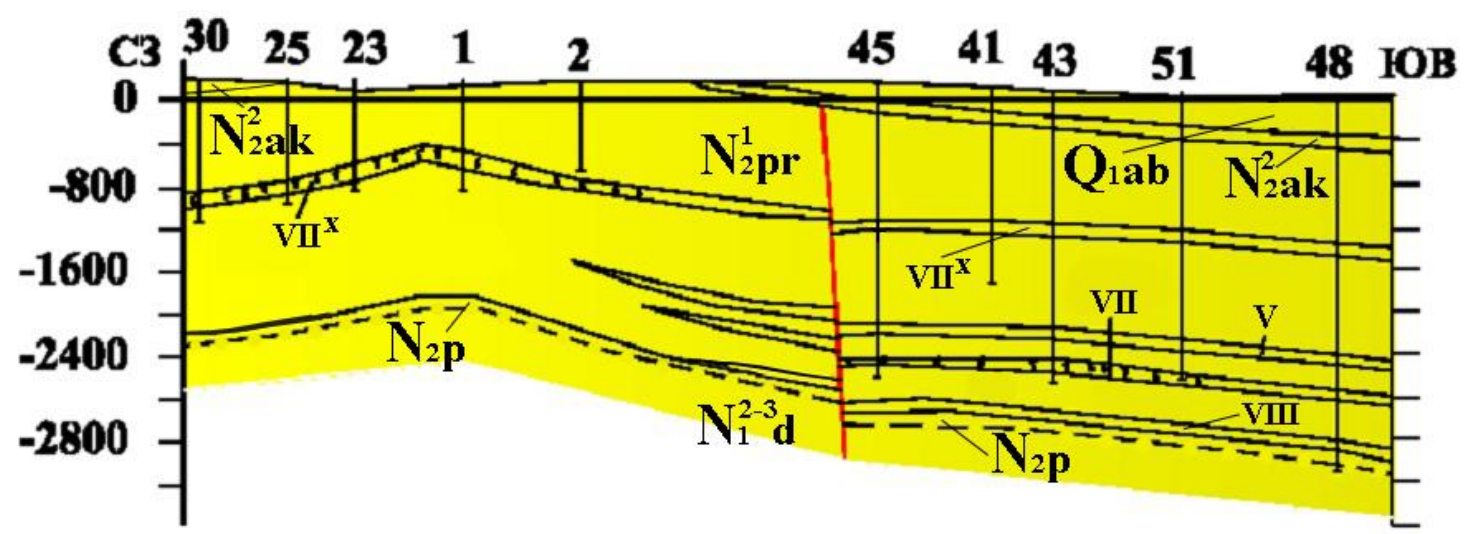

Рис. 7. Дуванны-дениз. Сейсмогеологический профиль (условные обозначения на рис. 6)

Fig. 7. Duvanni-deniz. Seismogeological profile (for legend see fig. 6)

\section{Результаты}

Все структуры западного борта ЮКВ осложнены радиальными, продольными и поперечными разрывными нарушениями. Исследования показали, что радиальные, поперечные разрывы затухают с глубиной и доходят до VII горизонта. Имеющие региональный характер и играющие основную роль во всех геологи- ческих процессах некоторые из радиальных и поперечных разрывов приурочены к грязевым вулканам $[1,6,9,19,23]$.

Изучение пространственного положения продольных нарушений сделало возможным уточнение особенностей изменения их вертикального смещения.

Изменяющаяся мощность стратиграфических единиц разного возраста также обусловлена разнород- 
ными продольными нарушениями, сыгравшими немаловажную роль в процессе формирования седиментационного бассейна и, косвенно повлиявшими на сам процесс осадконакопления. Осложнение присводовых участков всех структур этими разрывами совместно с поперечными и радиальными нарушениями) способствует формированию индивидуальных тектонических единиц, которые имеют различное пространственное положение. Все эти обстоятельства играют важную роль в распределении и сохранении выявленных залежей углеводородов. Надо отметить, что на исследуемой территории широко распространены залежи, сформировавшиеся в среде, где преобладали конседиментационные процессы. Все нарушения исследуемого региона оказывают неоднозначное влияние на формирование, перспективность и пространственное распределение УВ залежей. Нарушения, выполняющие экранирующую роль, преобладают над разрывами, являющимися проводниками при миграции флюидов. В итоге изучение разрывных нарушений имеет большое практическое значение как для определения их функциональной роли при формировании и разрушении УВ залежей, так и в последующих процессах при стадиях разработки и эксплуатации месторождений $[1,2,6,22,23]$.

Разнородность тектонических нарушений совместно с наличием сформировавшихся НАЛ различного типа объясняется тем, что рассматриваемые бассейны в различные периоды геологического времени развивались по-разному, т. е. геологические, тектонические процессы, происходящие в них, коренным образом отличались друг от друга. В результате этого на этих территориях сформировались различные типы неантиклинальных ловушек, которые в дальнейшем были осложнены тектоническими разрывами различного происхождения. Надо отметить, что именно эти разрывные нарушения, в зависимости от их природы, могут играть важную роль, как в формировании, так и в разрушении месторождений УВ.

\section{Выводы}

1. Причины образования распространенных в Куринской впадине неантиклинальных ловушек и осложняющих их тектонических нарушений резко отличаются от природы образования ловушек и осложняющих их разломов в ЮКВ. Разрывные

\section{СПИСОК ЛИТЕРАТУРЫ}

1. Геология нефтяных и газовых месторождений Азербайджана / А.А. Ализаде, Г.А. Ахмедов, А.М. Ахмедов, А.Л. Алиев, М.М. Зейналов. - М.: Недра, 1966. - 392 с.

2. Aliyeva E. Depositional environment of hydrocarbon-bearing Lower Pliocene productive series in South-West Caspian Basin // Proc. $16^{\text {th }}$ Sedimentological Congress. - South Africa, 2002. P. 9-12.

3. Narimanov A.A. Concept on the formation of the oil and gas fields in the South Caspian Basin // Trans action of the International Academy of Science. - 2005-2006. - V. 2. - P. 483-499.

4. Роль разрывной тектоники в понимании особенностей строения, формирования и разработки морских месторождений Среднего Каспия / А.Н. Лесной, Н.В. Дорофеев, А.В. Бочкарев, Е.В. Ананьева, Ю.С. Осипова, О.В. Щукина // Геология, нарушения, развитые в отдельных частях данного региона, имеют различное происхождение и особенности пространственного положения. Формирование разрывов в ЮКБ происходило в два этапа, в результате чего были образованы продольные глубинные разломы и вторичные разрывы, которые связаны непосредственно с грязевым вулканизмом, имеющие относительно неглубокое заложение и радиальную ориентировку в пространстве.

2. Нарушения, осложняющие структуры Куринской впадины (в основном Среднекуринской), не имеют определенного общего направления.

3. Лучшие экранирующие свойства наблюдаются у нарушений в пределах ЮКВ, где особенно можно выделить свиты нижнего отдела ПТ. В данном отделе преобладание непроницаемых глинистых отложений является отличительной чертой его литологического состава. Глинистые отложения, заполняя зоны трещиноватости разрывных нарушений, препятствуют разрушению УВ залежей.

4. Тектонически экранированные залежи в основном развиты в ЮКВ, а в Куринской впадине распространены залежи массивного типа, связанные с эрозионными выступами фундамента и эффузивными «ядрами». Тектонические нарушения, осложняющие структуры ЮКВ, являются производными от основного регионального глубинного разлома и являются «привязанными» к нему, тогда как тектонические нарушения структур Куринской впадины являются, с точки зрения развития, более самостоятельными. Пространственное положение структур Куринской впадины не проявляет такой явной закономерности в организации, как это происходит со структурами ЮКВ, где структуры имеют четко ориентированное пространственное расположение.

5. Выявленные особенности влияния разрывов как на процесс формирования залежей УВ, так и на их пространственное распределение можно использовать в качестве критерия при проведении поисково-разведочных работ для изучаемого региона. Это позволит дать научную оценку перспективам нефтегазоносности ловушек, связанных с тектоническими разрывами того или иного объекта и наметить рациональное проведение дальнейших поисково-разведочных работ.

геофизика и разработка нефтяных и газовых месторождений. - 2017. - № 3. - С. 22-33.

5. Воеводкин В.Л., Андреев К.В., Бондаренко М.М. Обустройство морских месторождений на шельфе Каспийского и Балтийского морей // Геология, геофизика и разработка нефтяных и газовых месторождений. - 2019. - № 3. - С. 15-20.

6. Керимов В.Ю., Мухтарова Х.З., Мустаев Р.Н. Дизъюнктивные нарушения и их роль в формировании и разрушении залежей нефти и газа в Южной Каспии // Нефть, газ и бизнес. - 2011. № 6. - С. 18-26.

7. Моделирование механизма генерации, аккумуляции и путей миграции углеводородов в Южно-Каспийской впадине / К.Н. Каграманов, Н.М. Ганиев, Х.З. Мухтарова, М.Т. Бабаева // Геология, геофизика и разработка нефтяных и газовых месторождений. - 2018. - № 6. - С. 37-45.

8. Akhmedbeyli F.S. Regional seismicity of the territory of Azerbaijan in connection with tectonic activation of the Central 
segment of Alpine-Himalay belt // Works of Institute of Geology of National Academy of Sciences of Azerbaijan. - Baku: Naftapress, 2001. - P. 40-47.

9. Кунин Н.Я., Кучерук Е.В. Сейсмостратиграфия в решении проблем поиска и разведки месторождений нефти и газа // Итоги науки и техники. - 1984. - № 12. - С. 24-31.

10. Abdullayev N.R. Seismic stratigraphy of the Upper Pliocene and Quaternary deposits in the South Caspian Basin // J. of Petroleum Sciences and Engineering. - 2000. - V. 28. - P. 207-226.

11. Юрова М.П. Особенности строения ёмкостного пространства рифогенных коллекторов среднего карбона месторождений Поволжья // Геология, геофизика и разработка нефтяных и газовых месторождений. - 2018. - № 5. - С. 26-29.

12. Мамедов П.З. Выявление рифогенных образований с помощью сейсмостратиграфических исследований // Геология нефти и газа. - 1986. - № 7. - С. 11-24.

13. Мамедов П.З. Перспективы поисков НАЛ в подошвенных свитах среднего плиоцена С3 части Абшеронского архипелага // Геология нефти и газа. - 1987. - № 4. - С. 32-49.

14. Мамедов П.З. Палеодельтовые осадочные формации по данным сейсмостратиграфического анализа // Геология нефти и газа. - 1989. - № 1. - С. 7-12.

15. Modern Caspian deltas as analogues for the productive series, Azerbaijan / K. Solomon, J.F. Boels, R.M. Hoogendoorn, I. Overeem, E. Aliyeva, D. Huseynov, E.M. Badyukova, A.A. Svitoch, D. Hinds, M.D. Simmons // Sandstone Deposition in Lacustrine Environments: Implications for Exploration and Reservoir Development: AAPG Hedberg Conference. - Baku, Azerbaijan, May 18-21, 2004. - P. 3-5.

16. Шлезингер А.Е. Региональная сейсмостратиграфия. - М. Научный мир, 1998. - 205 с.

\section{Информация об авторах}

Myxmapoвa X.3., кандидат геолого-минералогических наук, доцент кафедры геологии нефти и газа Азербайджанского Государственного Университета Нефти и Промышленности.
17. Narimanov A.A. The petroleum systems of the South Caspian Basin. Basin Modelling: advances and application // NPF Special Publication 3. - Amsterdam: Elsevier, 1993. - P. 599-608.

18. Гусейнов Б.Б., Салманов А.М., Магеррамов Б.И. Нефтегазогеологическое районирование территории суши Азербайджана. - Баку: Марс Принт, 2019. - 308 с.

19. Нариманов А.А.О перспективных направлениях и результатах поиского-разведочных работ, проведенных на морской и сухопутной территории Азербайджанской республики в начале XXI-го века // Геолог Азербайджана. - 2009. - № 13. - С. 40-57.

20. Багир-заде Ф.М., Керимов К.М., Салаев С.Г Глубинное строение и нефтегазоносность Южно-Каспийской мегавпадины. Баку: Аз. Гос. Издат., 1987. - 301 c.

21. Изучение нефтеносности площади Мишовдаг Нижнекуринской впадины в связи со структурно-тектоническими особенностями и новейшими геолого-геофизическими данными / Х.З. Мухтарова, Г.Д. Насибова, Ф.Н. Рагимов, М.Г. Ахмедов // Геология, геофизика и разработка нефтяных и газовых месторождений. -2016 . - № 8. - С. 28-36.

22. Региональная геология и нефтегазоносность Каспийского моря / И.Ф. Глумов, Я.П. Маловицкий и др. - М.: Недра, 2004. $-328 \mathrm{c}$

23. Гаджиев А.Н., Рагимханов Ф.Г. Тектоника Апшеронского архипелага и прилегающей части Бакинского архипелага в свете новых геофизических исследований // Азербайджанское Нефтяное Хозяйство. - 1982. - № 2. - С. 10-14.

Поступила 19.09.2019 г. 
UDC 553. 98(479.24): 550.8.072

\title{
ON THE TYPES OF TRAPS FORMED IN THE KUR AND SOUTH CASPIAN DEPRESSIONS AND THE ROLE OF TECTONIC FAULTS IN THEM
}

\author{
Khuraman Z. Mukhtarova, \\ mukhtarova.khuraman@mail.ru \\ Azerbaijan State Oil and Industry University, \\ 34, Azadliq avenue, Baku, AZE1010, Azerbaijan.
}

\begin{abstract}
The relevance of the study is caused by the fact that in Azerbaijan, as well as around of the world, oil and gas deposits associated with anticlinal types of traps are rapidly exhausted. Just this situation makes the issue relevant and requires studying the diverse, mainly nonanticlinal and combined traps and their prospects (where tectonic disturbances are of considerable importance). The carried out research can provide reliable information on the study of traps in both the Kura and South Caspian basins, which were developed in absolutely different geological and tectonic conditions.
\end{abstract}

The aim of the research is to determine the nature of tectonic evolution of the Kura and South Caspian basins areas and analyze the structure of heterogeneous traps formed in them.

Methods. Using a computer software the author has built a territory model and reconstructed paleotectonic conditions that clearly illustrate evolution and location of both depressions. As a result of modeling and research of the paleotectonic evolution of the region, it was revealed that if traps are characterized by the anticlinal type in the sandy horizons of the productive series within South Caspian depression, in the Kura depression they belong to non-anticlinal ones and are mainly associated with Paleogene-Miocene, Eocene and Upper Cretaceous age's layers.

Results. Anticlinal type traps are formed mainly as a result of horizontal tectonic stresses, but non-anticlinal traps are fully formed in conditions, reflecting various stages of the evolution of the earth's crust. Only tectonic movements play a significant role in occurrence of various forms of geological entities and geometric units in which various types of traps are formed, which morphologically differ from each other, depending on the influence of the main factor and the formation conditions. The studies have revealed that tectonically shielded deposits are mainly associated with the South Caspian depression, while the Kura depression is more appropriate for the formation of predominantly massive deposits associated with erosion protrusions of the basement and effusive "cores». Studying these issues allows predicting the prospect of finding complex traps in view of geometric detail and shape. The study of the conditions for formation of heterogeneous traps makes it possible to determine both their lithological composition and distribution ranges. In particular, it was determined that the spatial position of Kura depression structures to a certain extent differs from the structures of the South Caspian depression in terms of spatial location. In other words, it is not particularly possible to find a specific arrangement of structures in the Kura depression, while the folds within South Caspian depression clearly reflect the results of compressive stresses and their predominant role in the orientation of uplifts. Within the considered territory, the anticlinal, non-anticlinal, and combined type traps are mainly observed in deep lying deposits and they are of especial interest from the point of view of prospecting for oil and gas reserves. It should be taken inro account that, as a result of tectonic and other repeated effects, the formed traps have a more complex shape.

\section{Key words:}

Anticlinal, nonanticlinal, reservoir, hydrocarbons, movements, screen, process, wedging, trap, oil, gas, deposit.

\section{REFERENCES}

1. Alizade A.A., Akhmedov G.A., Akhmedov A.M., Aliyev A.K., Zeynalov M.M. Geologiya neftyanykh i qazovykh mestorozhdeniy Azerbaydjana [Geology of oil and gas fields of Azerbaijan]. Moscow, Nedra Publ., 1966. 392 p.

2. Aliyeva E. Depositional Environment of Hydrocarbon-Bearing Lower Pliocene Productive Series in South-West Caspian Basin. Proc. $16^{\text {th }}$ Sedimentological Congress. South Africa, 2002. pp. 9-12.

3. Narimanov A.A. Concept on the formation of the oil and gas fields in the South Caspian Basin. Transaction of the international Academy of Science, 2005-2006, vol. 2, pp. 483-499.

4. Lesnoy A.N., Dorofeev N.V., Bochkaryov A.V., Ananyeva Y.V., Osipova Y.S., Shukina O.V. The role of the faulting tectonics in understanding structural, formation, and development properties of The Middle Caspian marine oilfields. Geology, geophysics and development of oil and gas fields, 2017, no. 3, pp. 22-33. In Rus.

5. Voyevodkin V.L., Andreyev K.V., Bondarenko M.M. Construction of marine oilfields on the Caspian and Baltic sea shelves. Geology, geophysics and development of oil and gas fields, 2019, no. 3, pp. 15-20. In Rus.

6. Kerimov V.Y., Mukhtarova K.Z., Mustayev R.N. Disjunctive faults and their role in formation and destruction of oil and gas pools. Oil, gas and business, 2011, no. 6, pp. 18-26. In Rus.
7. Kagramanov K.N., Qaniyev N.M., Mukhtarova K.Z., Babayeva M.T. Simulating the workings of generation, accumulation and hydrocarbon migration ways in South Caspian Depression. Geology, geophysics and development of oil and gas fields, 2018, no. 6, pp. 37-45. In Rus.

8. Akhmedbeyli F.S. Regional seismicity of the territory of Azerbaijan in connection with tectonic activation of the Central segment of Alpine-Himalay belt. Works of Institute of Geology of National Academy of Sciences of Azerbaijan. Baku, Nafta-press, 2001. pp. 40-47.

9. Kunin N.Ya., Kucheruk E.V. Seysmostratigrafiya $v$ reshenii problem poiska i razvedki mestorozhdeniy nefti i qaza [Seismostratigraphy in solution of problems of exploration of oil and gas fields]. Itogi nauki i tekhniki, 1984, no. 12, pp. 24-31.

10. Abdullayev N.R. Seismic stratigraphy of the Upper Pliocene and Quaternary deposits in the South Caspian Basin. J. of Petroleum Sciences and Engineering, 2000, vol. 28, pp. 207-226.

11. Yurova M.P. Structural properties of spatial volumetrics of reef reservoir rocks of the Middle Carboniferous of the Povoljye oilfields. Geology, geophysics and development of oil and gas fields, 2018, no. 5, pp. 26-29. In Rus.

12. Mamedov P.Z. Vyyavlenie rifogennykh obrazovaniy s pomoshchyu seysmostratigraficheskikh issledovaniy [Identification of reef formations using seismostratigraphic studies]. Geologiya nefti $i$ gaza, 1986, no. 7, pp. 11-24. 
13. Mamedov P.Z. Perspektivi poiskov NAL v podoshvennykh svitakh srednego pliotsena SZ chasti Absheronskogo arkhiplaga [NAT exploration prospectivity within bottom suits of the Middle Pliocene of the NW part of the Absheron peninsular]. Geologiya nefti i gaza, 1987, no. 4, pp. 32-49.

14. Mamedov P.Z. Paleodeltovye osadochnye formatsii po dannym seysmostratigraficheskogo analiza [Paleodeltaic sedimentary formations according to seismostratigraphic analysis data]. Geologiya nefti i gaza, 1989, no. 1, pp. 7-12.

15. Solomon K., Boels J.F., Hoogendoorn R.M., Overeem I., Aliyeva E., Huseynov D., Badyukova E.M., Svitoch A.A., Hinds D., Simmons M.D. Modern Caspian Deltas as Analogues for the Productive Series, Azerbaijan. AAPG Hedberg Conference. Sandstone Deposition in Lacustrine Environments: Implications for Exploration and Reservoir Development. Baku, Azerbaijan, May 18-21, 2004. pp. 3-5.

16. Shlezinger A.E. Regionalnaya seysmostratigrafiya [Regiona seismostratigraphy]. Moscow, Nauchniy mir Publ., 1998. 205 p.

17. Narimanov A.A. The petroleum systems of the South Caspian Basin. Basin Modelling: advances and application. NPF Special Publication 3. Amsterdam, Elsevier, 1993. pp. 599-608.

18. Khuseynov B.B., Salmanov A.M., Magerramov B.I. Neftegazogeologicheskoe rayonirovanie territorii sushi Azerbaidjana [Geological oil and gas zonation of the Azerbaijan offshore territories]. Baku, Mars Print, 2019. 308 p.

19. Narimanov A.A. On prospective areas and results of exploration works carried out on the offshore and onshore territories of

\section{Information about the authors}

Khuraman Z. Mukhtarova, Cand. Sc., associate professor, Azerbaijan State Oil and Industry University.
Azerbaijan at the beginning of the XXI century. Azerbaijan geologist, 2009, no. 13, pp. 40-57. In Rus.

20. Bagir-zade F.M., Kerimov K.M., Salaev S.G. Glubinnoe stroenie i neftegazonosnost Yuzhno-Kaspiyskoy megavpadiny [Deep structure and oil and gas content of the South Caspian megadepression]. Baku, Az.Gos.Izdat. Publ., 1987. 301 p.

21. Mukhtarova K.Z., Nasibova G.D., Ragimov F.N., Akhmedov M.G. Studying oil content of the Mishovdag area of the Lower Kur depression in connection with structural and tectonic properties and latest geological and geophysical data. Geology, geophysics and development of oil and gas fields, 2016, no. 8, pp. 28-36. In Rus.

22. Glumov I.F., Malovitskiy Ya.P. Regionalnaya geologiya $i$ neftegazonosnost Kaspiyskogo morya [Regional geology and oil and gas content of the Caspian Sea]. Moscow, Nedra Publ., 2004. $328 \mathrm{p}$.

23. Gadzhiev A.N., Ragimkhanov F.G. Tektonika Absheronskogo arkhipelaga i prilegayushchey chasti Bakinskogo arkhipelaga v svete novykh geofizicheskikh issledovaniy [Tectonics of the Absheron archipelago and adjacent part of the Baku archipelago in the light of new geophysical studies]. Azerbaydjanskoe Neftyanoe Khozyaystvo, 1982, no. 2, pp. 10-14.

Received: 19 September 2019. 